\title{
GEORGES BONANI (1946-2020) AND RADIOCARBON DATING AT ETH ZURICH
}

Irka Hajdas (1)

Laboratory of Ion Beam Physics, ETHZ, HPK H25, Otto-Stern-Weg 5, Zurich 8093, Switzerland

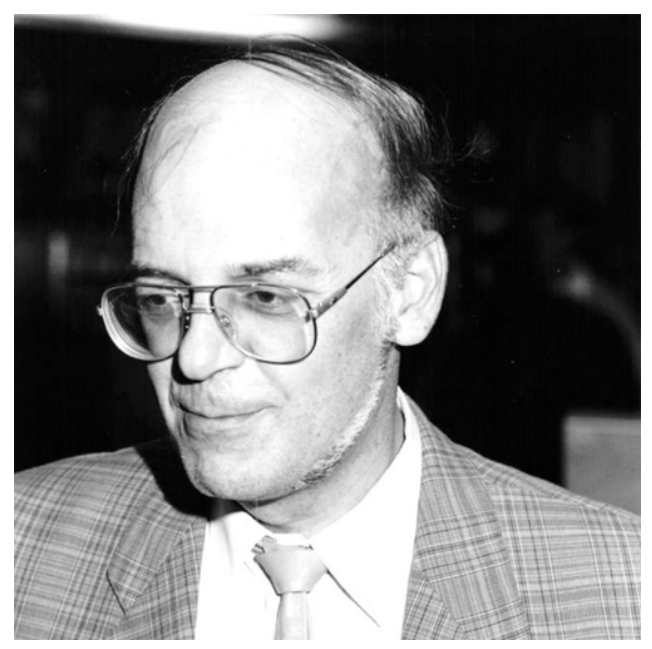

Georges Bonani at the AMS conference in Zurich, 1984

Looking back at a long and creative career in radiocarbon dating of Dr. Georges Bonani, one can say for sure that Georges had all qualities needed to build the solid reputation of the ETH ${ }^{14} \mathrm{C}$ laboratory. His background in physics (studies at ETH and his doctoral thesis (Bonani 1977) was essential to the development of the AMS by the team around Willy Wölfli (Bonani et al. 1984a; Suter et al. 1984; Synal et al. 2021). The first applications were published in the early 1980s (Bill et al. 1984; Bonani et al. 1984b; Giger et al. 1984). Until 2012, i.e., when the transition to the AMS ${ }^{14} \mathrm{C}$ analysis using MICADAS took place, Georges performed the demanding tuning of the EN $6 \mathrm{MV}$ tandem for ${ }^{14} \mathrm{C}$ analysis and data reduction. These would take place every 4 to 6 weeks, the time that Georges filled with talking to users, sampling unique objects and working on data, and sending the letters with results. His perfectly organized files are still my source of information whenever data produced 30 years ago has to be revisited. But the list of his involvement in our laboratory life is not ending there. He was always helpful with any questions. His problem-solving skills, so prominent with the EN tandem tuning, were appreciated in the group, and everyone could always count on his friendly support even with everyday issues.

Simultaneously, Dr. Bonani was one of the most cited scientists at ETH when the citation index started to be an important issue in the late 1990s. His involvement in studies which employed ${ }^{14} \mathrm{C}$ dating was not only by providing the AMS analysis. Georges was actively involved in data analysis and interpretation of the results. Often, he was also involved in designing the sampling strategies and supported experimental and pioneering approaches such as dating pollen grains

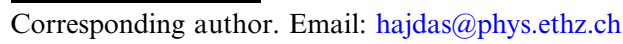


(Hauenstein 1994) and ${ }^{14} \mathrm{C}$ dating of paint (unpublished data). He was extremely helpful during my $\mathrm{PhD}$ project when measuring macrofossil samples as small as $0.3-0.5 \mathrm{mg}$ of carbon (Hajdas et al. 1993). In the early 1990s, that required a considerable effort, sometimes even manual running of the target to maximize the counts collected (targets were a flat disc). The experimentation was written into his "physicist's DNA." Moreover, Georges could often foresee the outcome and communicate it openly. Nevertheless, he would give his full support to all experiments if required by the project because he considered it a learning process.

Besides the remarkable work for archeology, especially Swiss archeology and climate research, Georges liked working with art. His office bookshelves were filled with publications, which included radiocarbon dating, for which he wrote short articles explaining the method. One must say that sometimes the experience had annoying consequences such as letters following the dating of the medieval textile known as the "Shroud of Turin" (Damon et al. 1989). Georges was always calm and good-humored, just waved them away and continued his work. The most remarkable effort was put into dating Anatolian textiles. Georges worked with Jürg Rageth on the book. They showed the power of radiocarbon dating (Rageth 1997) applied to objects from the last 300 years (previously, the wiggles between mid-17th and mid-20th century were considered a huge obstacle). Georges' interest in cultural heritage was contagious, and my projects dedicated to dating mortars and paintings are rooted in the first work by Bonani and Wölfli. They made the first excellent contacts with museums and art researchers as well as art connoisseurs. The most prominent samples, such as the Iceman found in the Alps (Bonani et al. 1994), the "Bundesbrief" (the Swiss Charter), and the Dead Sea Scrolls (Bonani et al. 1992) were radiocarbon dated at the ETH laboratory, which led to the media interest. The remarkable quality of the data produced in 1991 when dating the "Bundesbrief" is illustrated by the excellent agreement obtained using the modern AMS technique (Hajdas et al. 2019).

It was a privilege to work with Georges and learn from him about ${ }^{14} \mathrm{C}$ dating. He was a mentor, a good colleague, and a friend. From the time perspective, I can say that I have never met someone like Georges, who lived his professional life so intently at the same time it was so clear that he was very much a family person. One of the examples was a wooden slab from a birch tree that grew near his family home in Brig (VS) in southern Switzerland. For years, Georges had it in his office to explain tree rings, but I like to think that it reminded him of his hometown. At some point, this wood was a subject in one of our many school projects. Georges retired fully in 2015, and our contacts were limited to occasional phone calls. He was always happy to hear about the projects of the lab. Unfortunately, Georges' fragile health did not allow him to enjoy retirement time. He left us all too soon, but he is remembered by the radiocarbon community, and our thoughts are with his family.

\section{REFERENCES}

Bill J, Keller WA, Erne R, Bonani G, Wolfli W. 1984. C-14 dating of small archaeological samplesNeolithic to Iron-Age in the central Alpine region. Nuclear Instruments \& Methods in Physics Research Section B-Beam Interactions with Materials and Atoms 5(2):317-320.

Bonani G. 1977. Quantitative spurenanalyse mit ioneninduzierter Röntgenstrahlung. ETH Zurich.

Bonani G, Balzer R, Hofmann HJ, Morenzoni E, Nessi M, Suter M, Wolfli W. 1984a. Properties of milligram size samples prepared for AMS C14 dating at ETH. Nuclear Instruments \& Methods in Physics Research Section B-Beam Interactions with Materials and Atoms 5(2):284-288.

Bonani G, Ivy S, Wolfli W, Broshi M, Carmi I, Strugnell J. 1992. Radiocarbon dating of 14 Dead-Sea-Scrolls. Radiocarbon 34(3):843-849.

Bonani G, Ivy SD, Hajdas I, Niklaus TR, Suter M. 1994. AMS ${ }^{14} \mathrm{C}$ age-determinations of tissue, 
bone and grass samples from the Otztal Ice Man. Radiocarbon 36(2):247-250.

Bonani G, Satish J, Wanner HU, Wolfli W. 1984b. Sampling and analysis of particulate matter in the ambient air of Zurich. Nuclear Instruments \& Methods in Physics Research Section B-Beam Interactions with Materials and Atoms 3(13):493-497.

Damon PE, Donahue DJ, Gore BH, Hatheway AL, Jull AJT, Linick TW, Sercel PJ, Toolin LJ, B ronk CR, Hall ET, et al. 1989. Radiocarbon dating of the Shroud of Turin. Nature 337(6208):611-615.

Giger W, Sturm M, Sturm H, Schaffner C, Bonani G, Balzer R, Hofmann HJ, Morenzoni E, Nessi M, Suter M, et al. 1984. C-14/C-12-ratios in organicmatter and hydrocarbons extracted from dated lake-sediments. Nuclear Instruments \& Methods in Physics Research Section B-Beam Interactions with Materials and Atoms 5(2): 394-397.

Hajdas I, Ivy SD, Beer J, Bonani G, Imboden D, Lotter AF, Sturm M, Suter M. 1993. AMS radiocarbon dating and varve chronology of Lake Soppensee-6000 to 12000 C-14 years BP. Climate Dynamics 9(3):107-116.
Hajdas I, Synal H-A, Wacker L. 2019. Neue Möglichkeiten der $\quad{ }^{14} \mathrm{C}$-Datierung mittelalterlicher Objekte. Die verfeinerten Radiokarbon-Alter des Bundesbriefs von 1291 und der Thuner Handfeste von 1264. Hier und Jetzt.

Hauenstein J. 1994. Herstellung von mikrogrammgrossen Kohlenstoffproben für die Bestimmung des 14C-Gehaltes sowie Untersuchung von fossilen Pollen und polarem Gletschereis. Universität.

Rageth J. 1997. Anatolian kilims \& radiocarbon dating: a new approache to dating Anatolian kilims. Basel: Edition Jurg Rageth. 248 p.

Suter M, Balzer R, Bonani G, Hofmann $H$, Morenzoni E, Nessi M, Wolfli W, Andree M, Beer J, Oeschger H. 1984. PrecisionMeasurements of $\mathrm{C}-14$ in AMS-some results and prospects. Nuclear Instruments \& Methods in Physics Research Section B-Beam Interactions with Materials and Atoms $5(2): 117-122$.

Synal H-A, Beer J, Suter M. 2021. Willy Wölfli (1930-2014): a nuclear physicist with pioneering visions. Radiocarbon. doi: 10.1017/RDC. 2021.33 